\title{
Comparison of Multiple Intelligence Areas of Hearing and Visually Impaired Individuals in Terms of Age, Gender and State of Doing Sport
}

\author{
Deniz Özge Yüceloğlu Keskin ${ }^{1, *}$ \& Levent Bayram ${ }^{1}$ \\ ${ }^{1}$ Yaşar Doğu Faculty of Sport Sciences, Ondokuz Mayıs University, Turkey \\ *Corresponding author: Yaşar Doğu Faculty of Sport Sciences, Ondokuz Mayıs University, Turkey. Tel: \\ 90-533-747-4070. E-mail: ozge_yuceloglu@hotmail.com
}

Received: December 1, 2019

Accepted: December 17, 2019 Online Published: December 22, 2019

doi:10.5430/wje.v9n6p98

URL: https://doi.org/10.5430/wje.v9n6p98

\begin{abstract}
The purpose of the study is to review the multiple intelligence domains of the individuals belonging to two different disability groups (hearing impaired and visually impaired). The study comprises of 63 adults in total, 34 hearing impaired and 29 visually impaired. In order to obtain data, "Multiple Intelligence Inventory" developed by Gülşen (2015) was applied to the respondents as well as the descriptive questions. In the study, $t$ test and Mann Whitney $U$, and Kruskal Wallis and One Way ANOVA were used. When the multiple intelligence score averages were compared according to the gender variable, the interpersonal intelligence score averages of the females were found to be significantly different than that of the males $(\mathrm{p}<0.05)$. It was determined that the naturalistic intelligence score averages of the individuals at the age of 35 or above were significantly higher when the score averages of multiple intelligence domains were compared in terms of age variable and the bodily - kinesthetic intelligence of the individuals doing sports was seen to be significantly higher than those who did not do any sports $(\mathrm{p}<0.05)$. When the average scores of multiple intelligence domains were compared in regard to the state of disability variable, the mathematical-logical intelligence of the hearing impaired was found to be significantly higher than the visually impaired $(\mathrm{p}<0.05)$. The visual-spatial intelligence of the hearing impaired was observed to be significantly higher than the visually impaired $(p<0.05)$. The musical intelligence of the visually impaired was found to be significantly higher than the hearing impaired $(p<0.05)$. The intelligence score averages of the visually impaired were determined to be significantly higher than the hearing impaired for the interpersonal intelligence domain $(\mathrm{p}<0.05)$. It was found that the intrapersonal intelligence of the hearing impaired was higher than the visually impaired $(p<0.05)$. The less developed intelligence domains of the impaired can be worked actively and improved by making regulations in a way that the impaired can involve more in the social life and by allowing them to be exposed to environmental warnings more.
\end{abstract}

Keywords: hearing, impaired, visually impaired, multiple intelligence, intelligence, sport

\section{Introduction}

Howard Gardner (2004) defines intelligence as the capacity of a person to produce a product that finds value in one or more cultures and the ability of a person to find effective and efficient solutions to the problems encountered in real life (Gardner, 2004). On the other hand, Woolfolk expresses intelligence as the ability of an individual to adapt to new environments and situations (Woolfolk, 2010).

Intelligence was thought to have only two dimensions many years ago. One of them was linguistic and the other was mathematical intelligence domains.

Bringing a new approach to intelligence in the $20^{\text {th }}$ century, Gardner, however, sees intelligence as a bio-psychological potential and as the ability to shape a product having value in one or more structures or the ability to solve problems. He argues that human intelligence can be regarded as a neural mechanism or computer system that is genetically programmed to get ready or "triggered" with the information from inside and outside (Avanoğlu, 2006).

It is possible to define the 8 different types of intelligence supported by Gardner briefly as follows:

- Verbal - Linguistic Intelligence: the ability to use words effectively both verbally and in writing;

- Logical - Mathematical Intelligence: the ability to use numbers effectively and to establish cause-effect relationships 
and to make effective reasoning about the formation and process of the events;

- Visual - Spatial Intelligence: the ability to read maps, to draw sketches, to think through pictures and figures and to express oneself in non-verbal forms;

- Musical Intelligence: the ability to perceive, distinguish and express musical forms;

- Bodily - Kinesthetic Intelligence: the ability to use the whole body to express emotions and thoughts, to use hands effectively and to produce new things with hands;

- Interpersonal Intelligence: the ability to understand the emotions, desires, interests and needs of the people around;

- Intrapersonal Intelligence: the ability to know oneself and to show behaviors accordant with the environment with the knowledge and understanding about oneself;

- Naturalistic Intelligence: the ability of an individual to recognize living organisms such as plants and animals, to classify them according to their specific characteristics and to distinguish them from others (Gardner, 1999).

With the Multiple Intelligence Theory set forth by him, Gardner freed intelligence from unidimensionality and argued that human intelligence should be evaluated in multiple ways. According to this theory, intelligence is the ability to shape a product that has value in one or more cultural structures or to solve problems (Bümen, 2002).

According to WHO (2018), disability is the term which expresses all the situations where there are bodily limitations, which limit activities and prevent participation. For the Organization, the concept of disability is the problems seen in the body parts, the inability to perform certain activities due to these problems and their negative impact on the life of the individual. Disability is not only a health problem relating to the body of the individual, but also a broader term with its effects on the social life and psychological well- being of the individual (WHO, 2018).

Öztürk (2011) görme ve işitme engelliğin tanımını şu şekilde yapmaktadır;

Visual Disability: Complete or partial vision problems in one eye or both eyes;

Hearing Disability: Complete or partial hearing problem in one ear or both ears. In case the individuals use hearing aids, they are also considered hearing impaired.

Organs of seeing and hearing are defined as "primary sensory organs" among the five senses, while organs of touch, smell and taste are defined as "secondary sensory organs" (Cavkaytar and Diken, 2005).

In special education, there are individuals with various physical and mental inabilities. One of these inabilities is the visual disability that affects the life of the individuals negatively in social and educational aspects since young ages. It is estimated that $85 \%$ of the knowledge of people with normal visual ability is acquired through seeing (Cavkaytar and Diken, 2012).

There is another concept among the visually impaired that should be defined, which is low vision. Individuals with low vision are those who have a visual acuity between $20 / 70$ and 20/200. Such visually impaired individuals can see from between 2 to $60 \mathrm{~cm}$ what normal people can see from 6 meters (Özsoy et al., 2005).

The term hearing impairment is most commonly used to describe individuals with hearing disability (Friend, 2006). All behaviors are the result of learning. The learning process for hearing impaired individuals is more difficult and requires more effort than healthy individuals (Özsoy et al., 1998). Hearing impairment is a condition that negatively affects social adaptation and communication skills. The most important effect of hearing loss is experienced in relation with understanding and expressing the language (Ekim and Ocakçı, 2010).

The purpose of the study is to review the multiple intelligence domains of individuals belonging to two different disability groups (hearing impaired and visually impaired) in terms of different variables.

\section{Method}

2.1 This Is a Descriptive Study Aimed at Examining the Multiple Intelligence Domains of Visually Impaired and Hearing Impaired Individuals According to Certain Variables

The study consisted of 63 adults in total, 34 hearing impaired and 29 visually impaired individuals, between the ages of 16 to 58 , in 2017. This study was applied to voluntarily individuals who are members of the Visually Impaired and Hearing Impaired associations in Samsun and Istanbul. Individuals who were actively doing sport and who had athlete licence from both disability groups were included in the study since mental areas of the impaired individuals will be examined in terms of status of doing sport. The inclusion of non-athlete disabled individuals was based on voluntariness. The questionnaires were given to individuals who participated in the study in the form of face-to-face 
interview. During the completion of the scale, the researcher who applied the scale accompanied the executive experts and in order to avoid incomplete and/or incorrect filling of the scales, the scales completed by the classroom teachers were examined one by one while the scales were received and the incomplete and/or incorrect scales were requested to be refilled.

In order to obtain data, "Multiple Intelligence Inventory" developed by Gülşen (2015) was applied to the respondents in addition to the descriptive questions about age, gender, educational background and whether they did sports or not.

\subsection{Multiple Intelligences Survey}

This survey was used to find out the students' multiple intelligence profiles. The Multiple Intelligences Survey contained 80 statements, addressing to eight intelligence types. The first category included statements from 1 to 10 addressing, verbal-linguistic intelligence. The second category included statements from 11 to 20 addressing, logical-mathematical intelligence. In the third category, statements from 21 to 30, focused on visual-spatial intelligence. In the fourth category, statements from 31 to 40, referred to musical intelligence. The fifth category included statements from 41 to 50 emphasizing naturalistic intelligence. The sixth category, statements from 51 to 60 , covered interpersonal intelligence. The seventh category, statements from 61 to 70 , addressed bodily-kinesthetic intelligence. Lastly, in the eighth category, statements from 71 to 80 , focused on intrapersonal intelligence.

All questions in the survey were in Turkish. The statements in the survey were based on a 5-point Likert-type rating scale, which were $0=$ the statement does not describe you at all, $1=$ the statement describes you very little, $2=$ the statement describes you somewhat, $3=$ the statement describes you pretty well and $4=$ the statement describes you exactly. The participants were asked to complete the survey by putting a check next to each statement that accurately described them (Subaşı 2014).

The data were analyzed through SPSS 22 packaged software. Shapiro-Wilk and Kolmogorov Smirnov tests were used to determine whether the data showed normal distribution or not. In the study, for the paired comparisons, $t$ test and Mann Whitney U test were used, and for the triple comparisons and above, Kruskal Wallis and One Way ANOVA tests were used to compare multiple intelligence theory score averages of the handicapped individuals in terms of the variables of gender, age, educational background and whether they did sports or not. Then,

The descriptive statistics (average, standard deviation, median, minimum and maximum values) of the variables were calculated. The level of significance was taken as $(\mathrm{p}<0.05)$.

\section{Results}

Table 1. Comparison of the Score Averages of Multiple Intelligence Types According to Gender Variable

\begin{tabular}{|c|c|c|c|c|c|c|c|c|}
\hline Intelligences Area & Gender & $\mathrm{N}$ & Mean & $\mathrm{Sd}$ & Median & Min & Max & $\mathrm{P}$ \\
\hline \multirow{2}{*}{ Verbal - Linguistic } & Female & 20 & 23,25 & 5,334 & 23,50 & 15 & 34 & \multirow{2}{*}{,744 } \\
\hline & Male & 43 & 22,37 & 6,095 & 23,00 & 8 & 36 & \\
\hline \multirow{2}{*}{ Logical - Mathematical } & Female & 20 & 17,05 & 7,605 & 18,00 & 4 & 28 & \multirow{2}{*}{,886 } \\
\hline & Male & 43 & 16,72 & 8,838 & 16,00 & 2 & 37 & \\
\hline \multirow{2}{*}{ Visual - Spatial } & Female & 20 & 21,60 & 7,930 & 21,50 & 8 & 36 & \multirow{2}{*}{, 152} \\
\hline & Male & 43 & 18,35 & 8,434 & 19,00 & 1 & 35 & \\
\hline \multirow{2}{*}{ Musical - Rhythmic } & Female & 20 & 16,40 & 9,779 & 17,00 & 0 & 30 & \multirow{2}{*}{,716 } \\
\hline & Male & 43 & 17,51 & 11,859 & 18,00 & 0 & 40 & \\
\hline \multirow{2}{*}{ Naturalistic } & Female & 20 & 26,90 & 8,771 & 28,00 & 12 & 38 & \multirow{2}{*}{, 185} \\
\hline & Male & 43 & 23,58 & 9,300 & 22,00 & 4 & 40 & \\
\hline \multirow{2}{*}{ Interpersonal } & Female & 20 & 27,70 & 6,359 & 29,00 & 16 & 40 & \multirow{2}{*}{, $043 *$} \\
\hline & Male & 43 & 23,56 & 7,823 & 23,00 & 9 & 40 & \\
\hline \multirow{2}{*}{ Bodily - Kinesthetic } & Female & 20 & 26,25 & 5,533 & 27,00 & 16 & 36 & \multirow{2}{*}{,912 } \\
\hline & Male & 43 & 26,00 & 6,004 & 28,00 & 9 & 36 & \\
\hline \multirow{2}{*}{ Intrapersonal } & Female & 20 & 27,15 & 4,955 & 25,50 & 21 & 36 & \multirow{2}{*}{,404 } \\
\hline & Male & 43 & 26,02 & 4,950 & 25,00 & 13 & 35 & \\
\hline
\end{tabular}


When the average scores of multiple intelligence types are compared according to gender variable in Table 1, the interpersonal intelligence score averages of females are found to be significantly different than males $(p<0.05)$. No significant difference is determined between the score averages of other intelligence types in terms of gender variable $(\mathrm{p}>0.05)$.

Table 2. Comparison of the Score Averages of Multiple Intelligence Types with Regard to Age Group Variable

\begin{tabular}{|c|c|c|c|c|c|c|c|c|}
\hline Intelligences Area & Age & $\mathrm{N}$ & Mean & $\mathrm{Sd}$ & Median & Min & Max & $\mathrm{P}$ \\
\hline & $16-25$ age & 26 & 22,50 & 6,701 & 23,00 & 8 & 36 & \\
\hline \multirow[t]{3}{*}{ Verbal - Linguistic } & $26-35$ age & 21 & 21,62 & 5,371 & 22,00 & 12 & 32 &, 523 \\
\hline & above 35 age & 16 & 24,13 & 4,843 & 24,00 & 15 & 33 & \\
\hline & $16-25$ age & 26 & 19,88 & 7,967 & 22,00 & 4 & 34 & \\
\hline \multirow[t]{3}{*}{ Logical - Mathematical } & $26-35$ age & 21 & 14,33 & 8,839 & 13,00 & 2 & 37 & \\
\hline & above 35 age & 16 & 15,13 & 7,356 & 15,00 & 4 & 28 & \\
\hline & $16-25$ age & 26 & 21,31 & 9,628 & 23,50 & 1 & 36 & \\
\hline \multirow[t]{3}{*}{ Visual - Spatial } & $26-35$ age & 21 & 16,81 & 7,541 & 17,00 & 2 & 30 & , 126 \\
\hline & above 35 age & 16 & 19,63 & 6,510 & 19,00 & 12 & 34 & \\
\hline & $16-25$ age & 26 & 17,42 & 11,490 & 20,00 & 0 & 36 & \\
\hline \multirow[t]{3}{*}{ Musical - Rhythmic } & $26-35$ age & 21 & 15,76 & 11,238 & 14,00 & 0 & 35 & ,749 \\
\hline & above 35 age & 16 & 18,56 & 11,075 & 20,00 & 0 & 40 & \\
\hline & $16-25$ age & 26 & $23,58^{\mathrm{b}}$ & 9,007 & 24,00 & 4 & 40 & \\
\hline \multirow[t]{3}{*}{ Naturalistic } & $26-35$ age & 21 & $17,79^{\mathrm{b}}$ & 6,740 & 20,00 & 7 & 37 &, $002 *$ \\
\hline & above 35 age & 16 & $31,31^{\mathrm{a}}$ & 9,185 & 34,50 & 12 & 40 & \\
\hline & $16-25$ age & 26 & 23,50 & 6,825 & 25,50 & 9 & 34 & \\
\hline \multirow[t]{3}{*}{ Interpersonal } & $26-35$ age & 21 & 23,62 & 7,446 & 24,00 & 9 & 36 & 059 \\
\hline & above 35 age & 16 & 28,75 & 8,071 & 30,00 & 17 & 40 & \\
\hline & $16-25$ age & 26 & 27,04 & 6,063 & 28,00 & 9 & 36 & \\
\hline \multirow[t]{3}{*}{ Bodily - Kinesthetic } & $26-35$ age & 21 & 25,29 & 5,858 & 27,00 & 15 & 34 & ,550 \\
\hline & above 35 age & 16 & 25,56 & 5,477 & 26,00 & 14 & 33 & \\
\hline & $16-25$ age & 26 & 26,69 & 6,272 & 27,00 & 13 & 36 & \\
\hline \multirow[t]{2}{*}{ Intrapersonal } & $26-35$ age & 21 & 26,71 & 4,485 & 26,00 & 20 & 36 & ,594 \\
\hline & above 35 age & 16 & 25,44 & 2,683 & 24,50 & 21 & 30 & \\
\hline
\end{tabular}

The naturalistic intelligence score averages of the individuals at the age of 35 or above are found to be significantly higher than other age groups when the average scores of multiple intelligence types are compared with regard to age variable in Table $2(p<0.05)$. No significant difference is observed between the score averages of other intelligence types in terms of age variable $(\mathrm{p}>0.05)$. 
Table 3. Comparison of the Score Averages of Multiple Intelligence Types According to Whether the Participants Do Sports or Not

\begin{tabular}{|c|c|c|c|c|c|c|c|c|}
\hline Intelligences Area & Sporting Status & $\mathrm{N}$ & Mean & $\mathrm{Sd}$ & Median & Min & Max & $\mathrm{P}$ \\
\hline \multirow{2}{*}{ Verbal - Linguistic } & Sports & 45 & 22,40 & 36,064 & 23,00 & 8 & 36 & \multirow{2}{*}{,778 } \\
\hline & Non-sports & 18 & 23,17 & 5,501 & 22,00 & 12 & 33 & \\
\hline \multirow{2}{*}{ Logical - Mathematical } & Sports & 45 & 17,09 & 8,090 & 18,00 & 4 & 37 & \multirow{2}{*}{,697 } \\
\hline & Non-sports & 18 & 16,17 & 9,364 & 15,50 & 2 & 34 & \\
\hline \multirow{2}{*}{ Visual - Spatial } & Sports & 45 & 19,98 & 8,086 & 20,00 & 1 & 36 & \multirow{2}{*}{, 374} \\
\hline & Non-sports & 18 & 17,89 & 9,055 & 17,50 & 2 & 35 & \\
\hline \multirow{2}{*}{ Musical - Rhythmic } & Sports & 45 & 16,89 & 11,173 & 18,00 & 0 & 40 & \multirow{2}{*}{, 765} \\
\hline & Non-sports & 18 & 17,83 & 11,470 & 17,00 & 0 & 36 & \\
\hline \multirow{2}{*}{ Naturalistic } & Sports & 45 & 23,51 & 8,727 & 22,00 & 4 & 40 & \multirow{2}{*}{, 126 } \\
\hline & Non-sports & 18 & 27,44 & 9,984 & 29,50 & 8 & 40 & \\
\hline \multirow{2}{*}{ Interpersonal } & Sports & 45 & 24,96 & 7,483 & 25,00 & 10 & 40 & \multirow{2}{*}{,893 } \\
\hline & Non-sports & 18 & 24,67 & 8,073 & 25,00 & 9 & 40 & \\
\hline \multirow{2}{*}{ Bodily - Kinesthetic } & Sports & 45 & 27,51 & 5,413 & 29,00 & 9 & 36 & \multirow{2}{*}{, 001} \\
\hline & Non-sports & 18 & 22,50 & 5,339 & 21,00 & 14 & 31 & \\
\hline \multirow{2}{*}{ Intrapersonal } & Sports & 45 & 27,04 & 5,117 & 26,00 & 13 & 36 & \multirow{2}{*}{,097 } \\
\hline & Non-sports & 18 & 24,72 & 4,142 & 24,50 & 18 & 32 & \\
\hline
\end{tabular}

In Table 3, the average multiple intelligence scores of the participants are compared according to whether they do sports or not and the bodily-kinesthetic intelligence domain of those doing sports is found to be significantly higher $(\mathrm{p}<0.05)$. No significant difference is determined between the score averages of multiple intelligence types according to the variable of doing sports or not $(\mathrm{p}>0.05)$.

Table 4. Comparison of the Score Averages of Multiple Intelligence Types with Regard to State of Disability Variable

\begin{tabular}{|c|c|c|c|c|c|c|c|c|}
\hline Intelligences Area & İmpaired Status & $\mathrm{N}$ & Mean & $\mathrm{Sd}$ & Median & Min & Max & $\mathrm{P}$ \\
\hline \multirow{2}{*}{ Verbal - Linguistic } & Hearing & 34 & 21,56 & 6,990 & 22,00 & 8 & 36 & \multirow{2}{*}{,119 } \\
\hline & Visually & 29 & 23,86 & 3,843 & 23,00 & 16 & 33 & \\
\hline \multirow{2}{*}{ Logical - Mathematical } & Hearing & 34 & 18,82 & 6,649 & 18,00 & 7 & 34 & \multirow{2}{*}{, 037} \\
\hline & Visually & 29 & 14,48 & 9,687 & 10,00 & 2 & 37 & \\
\hline \multirow{2}{*}{ Visual - Spatial } & Hearing & 34 & 24,00 & 6,688 & 24,50 & 2 & 36 & \multirow{2}{*}{,000 } \\
\hline & Visually & 29 & 13,97 & 6,748 & 13,00 & 1 & 34 & \\
\hline \multirow{2}{*}{ Musical - Rhythmic } & Hearing & 34 & 11,94 & 10,328 & 8,50 & 0 & 30 & \multirow{2}{*}{, 000} \\
\hline & Visually & 29 & 23,28 & 8,884 & 25,00 & 5 & 40 & \\
\hline \multirow{2}{*}{ Naturalistic } & Hearing & 34 & 24,41 & 8,525 & 24,50 & 4 & 40 & \multirow{2}{*}{,837 } \\
\hline & Visually & 29 & 24,90 & 10,076 & 22,00 & 7 & 40 & \\
\hline \multirow{2}{*}{ Interpersonal } & Hearing & 34 & 22,91 & 6,730 & 24,00 & 9 & 36 & \multirow{2}{*}{,025 } \\
\hline & Visually & 29 & 27,17 & 8,005 & 27,00 & 9 & 40 & \\
\hline \multirow{2}{*}{ Bodily - Kinesthetic } & Hearing & 34 & 26,59 & 5,450 & 27,50 & 9 & 36 & \multirow{2}{*}{,456 } \\
\hline & Visually & 29 & 25,48 & 6,260 & 27,00 & 14 & 35 & \\
\hline \multirow{2}{*}{ Intrapersonal } & Hearing & 34 & 28,06 & 5,216 & 29,00 & 13 & 36 & \multirow{2}{*}{,001 } \\
\hline & Visually & 29 & 24,41 & 24,00 & 16,00 & 34 & 34 & \\
\hline
\end{tabular}


When the average scores of multiple intelligence domains are compared in regard to the state of disability variable in Table 4, the mathematical-logical intelligence of the hearing impaired is found to be significantly higher than the visually impaired $(\mathrm{p}<0.05)$. The visual-spatial intelligence of the hearing impaired is determined to be significantly higher than the visually impaired $(\mathrm{p}<0.05)$. The musical intelligence of the visually impaired is seen to be significantly higher than the hearing impaired $(\mathrm{p}<0.05)$. The intelligence score averages of the visually impaired is determined to be significantly higher than the hearing impaired for the interpersonal intelligence domain $(p<0.05)$. The intrapersonal intelligence of the hearing impaired is found to be higher than the visually impaired $(\mathrm{p}<0.05)$.

\section{Discussion}

In this study, it was aimed to review the multiple intelligence levels of hearing and visually impaired individuals according to different variables. A total of 63 adults, 34 hearing impaired and 29 visually impaired, between the ages of 16 and 58, participated in the study.

When the average scores of multiple intelligence types were compared according to gender variable, the average scores of interpersonal intelligence of females were found to be significantly different than that of males $(p<0.05)$. In a study conducted by Loori (2005), it was found that the interpersonal intelligence average scores of females were statistically significantly higher than that of males $(\mathrm{p}<0.05)$. This result is in parallel with the study. On the other hand, Doğan (2007) found out that "Logical-Mathematical, Bodily and Naturalist" intelligence domains of male participants were significantly higher than females ( $\mathrm{p}>0.05)$.

It was seen after the comparison of the score averages of the multiple intelligence types in terms of age variable that the naturalistic intelligence of the individuals over 35 was significantly higher than other age groups $(\mathrm{p}<0.05)$. The childhood and adolescence periods of the handicapped individuals over 35 years of age included the years when the physical environment was not concreted as much as it is today and settlement was lower unlike today. The children of that period were more advantageous than the children of today in terms of being in natural environments. More exposure to the natural environment during the childhood period when the intelligence domains develop the most rapidly may result in the development of the naturalistic intelligence of the individuals.

When the multiple intelligence score averages were compared with regard to the state of doing sports, the bodily-kinesthetic intelligence of the individuals doing sports was found to be significantly higher than those who did not do sports $(p<0.05)$. In their study Kiremitçi and Canpolat (2014) determined that considering the intelligence domains of the students at the school of physical education and sports, the students got the highest average scores in bodily- kinesthetic intelligence domain and this result was followed by the averages taken from the interpersonal/social intelligence domain with a very small difference (Kiremitci and Canpolat,014). Likewise, Hoşgörür and Katranc1 (2007) also found that students at the school of physical education and sports got the highest average in bodily-kinesthetic intelligence domain (Hoşgörür and Katrancı, 2007)

When the score averages of multiple intelligence types were compared in terms of the state of disability variable, the mathematical - logical intelligence of the hearing impaired was found to be significantly higher $(\mathrm{p}<0.05)$. According to Gardner (1999), mathematical - logical intelligence is the ability to use the number effectively, to establish cause-effect relationships and to make efficient reasoning about the formation and functioning of events. The hearing impaired individuals can perceive what is happening around them visually and interpret multi- dimensionally. When conducting the reasoning process, they can even use it more effectively without being exposed to the effects of different stimuli that may distract cognitive attention.

It was found that the visual-spatial intelligence of the hearing impaired was significantly higher than the visually impaired $(p<0.05)$. The sense of sight enables the individuals to position their body, and helps creation of the perception of distance, proximity and depth between the objects; therefore, it is thought that as these abilities of the visually impaired individuals cannot be developed, they can use the visual-spatial intelligence domain at a more limited level than the hearing impaired.

The musical intelligence of the visually impaired was found to be significantly higher than the hearing impaired $(\mathrm{p}<0.05)$. According to Bilen (1995), skills such as distinguishing sounds according to the lengthiness-shortness differences, repeating a played rhythmic motive, finding the rhythm of the known melody or rhyme among the options consisting of different rhythmic motives, and understanding the rhythmic structure of a song are related to the ability of musical hearing (Bilen, 1995). The sense of hearing is the most important requirement for the execution of these abilities and the development of musical intelligence. The inadequacy or lack of this sense causes the failure of performing these skills and limits the development of this intelligence domain. 
The intelligence score averages of the visually impaired individuals in interpersonal intelligence domain was found to be significantly higher than the hearing impaired $(\mathrm{p}<0.05)$. Social Intelligence is the capacity not to be able to understand the moods and attitudes of the people, to be able to empathize, to be able to understand the emotions, needs and expectations and to be able to behave accordingly (Saban, 2005). The most important way of the interpersonal communication is verbal communication. Individuals share their emotions and thoughts and interact with each other through verbal communication. The most important communication for the hearing impaired individuals who do not have verbal communication ability is body language and sing language. It is nearly impossible for the hearing impaired to communicate healthily with the other individuals in the society who do not know or cannot use sign language. The visually impaired individuals have a more advantageous position than the hearing impaired in terms of the diversity and abundance of people to communicate with in the society.

It was determined that the intrapersonal intelligence of the hearing impaired was higher than that of visually impaired $(p<0.05)$. Intrapersonal Intelligence is the individuals' awareness of their own expectations, needs, emotions, thoughts, deficiencies, and abilities (Özden, 2008). The ability of moving independently enables the individuals to perform a number of activities that ensure realization of themselves. The diversity of daily activities and the facilities they can reach on their own constitute a situation in favor of the hearing impaired individuals in terms of the development of the intrapersonal intelligence domain.

\section{Conclusion}

Training programs or camp organizations can be organized in which young people will get away from the technological world which includes a big part of their lives and be in the natural life and young people can be motivated and encouraged to participate in these.

Due to the promoting effect of sport participation on bodily-kinaesthetic intelligence, enabling visually and hearing impaired individuals to participate in physical activities more can increase their daily life skills and their capacity of being self-sufficient.

Programs supporting the participation of the handicapped individuals into social, cultural and sports activities that will improve their life quality should be implemented. The less developed intelligence domains of the handicapped can be worked actively and improved by making regulations in a way that the handicapped can involve more in the social life and by allowing them to be exposed to environmental warnings more.

\section{References}

Avanoğlu, A. (2006). Türkçe Dersindeki Başarı İle Çoklu Zekâ Alanları Arasındaki İlişki Düzeyi (Kastamonu Örneği). Yüksek Lisans Tezi, Abant İzzet Baysal Üniversitesi, Bolu/Turkey.

Bilen, S. (1995). İşbirlikli Öğrenmenin Müzik Öğretimi ve Güdüsel Süreçler Üzerindeki Etkileri. Doktora Tezi, Dokuz Eylül Üniversitesi. İzmir/Turkey.

Bümen, N.T. (2002). Okulda Çoklu Zeka Kuramı. Ankara: Pegem Yayıncılık.

Cavkaytar, A., \& Diken, İ. H. (2005). Özel Eğitime Giriş. 1. Bask1, Ankara, Kök Yayıncılık, 39-42.

Cavkaytar, A., \& Diken, İ. H. (2012). Özel Eğitim: Özel Ĕğitim ve Özel Eğitim Gerektirenler. Ankara: Vize.

World Health Organization (2018). Disabilities. Geneva.

Doğan, Y., \& Alkış, S. (2007). Sınıf Öğretmeni Adaylarının Sosyal Bilgiler Derslerinde Çoklu Zekâ Alanlarını Kullanabilmelerine Yönelik Görüşleri. Eğitim Fakültesi Dergisi, 20(2), 327-339.

Ekim, A., \& Ocakçı, A. F. (2012). 8-12 Yaş Arası İşitme Engelli Çocukların Yaşam Kalitesi. Ankara Sağllk Hizmetleri Dergisi, 11(1), 17-23. http://dx.doi.org/10.5606/fng.btd.2018.028

Friend, M. (2006). Special Education. Contemporary Perspectives for School Professionals. Boston: Allyn and Bacon.

Gardner, H. (1999). Intelligence Reframed: Multiple Intelligences for the 21st Century. New York, NY: Basic Books.

Gardner, H. (2004). Zihin Çerçeveleri: Zekâ Kuramı. Ebru Kılıç (Çev.). İstanbul: Alfa.

Gülşen, C. (2015). Multiple Intelligences Areas Evaluation Scale Developing Study. Journal of Human Sciences, 12(2), 1918-1930. http://dx.doi.org/10.14687/ijhs.v12i2.3469

Kiremitci, O., \& Canpolat, A. M. (2014). Beden Eğitimi ve Spor Yüksekokulu Öğrencilerinin Çoklu Zekâ 
Alanlarının Üstbilişsel Farkındalık ve Problem Çözme Becerilerini Belirlemedeki Rolü. Spor Bilimleri Dergisi, 25(3), 118-126.

Lewis, V. (2003). Development and Disability (2nd ed.). Malden, USA: Blackwell Publishing

Loori, A. A. (2005). Multiple intelligences: A Comperative Study between the Preferences of Males and Females. Social Behavior and Personality, 33(1), 77-88. https://doi.org/10.2224/sbp.2005.33.1.77

Özden, Y. (2008). Öğrenme ve Öğretme, Ankara: Pegem Akademi.

Özsoy, Y., Özyürek, M., \& Eripek, S. (2002). Özel Eğitime Giriş, 12. Bask1, Ankara, Karatepe Yayınları. 26.

Öztürk, M. (2011). Türkiye`de Engelli Gerçeği. MÜSİAD Cep Kitapları: İstanbul.

Saban, A. (2005). Çoklu Zeka Teorisi ve Eğitim. Ankara: Nobel Yayın Dağıtım.

Scheetz, N. A. (2004). Psychosocial Aspects of Deafness. Boston: Pearson Education, Inc

Subaş1, S. (2014). A Case Study on a Vocabulary Development Program Based on Multiple Intelligence Theory. Master Thesis. Çağ University Institute of Social Sciences. Mersin/Turkey.

Woolfolk, A. (2010). Eğitim Psikolojisi. D. Özen (Çev.). İstanbul: Kaktüs. 